\title{
Mengembalikan Fungsi Kognisi Pasien Penyakit Jantung di RSI Sunan Kudus Melalui Layanan Bimbingan Islam
}

\author{
Susana Aditiya Wangsanata \\ Universitas Islam Negeri (UIN) Walisongo \\ sswangsanata5@gmail.com \\ Ali Murtadho \\ Universitas Islam Negeri (UIN) Walisongo \\ ali_murtadho@walisongo.ac.id \\ Ema Hidayanti \\ Universitas Islam Negeri (UIN) Walisongo \\ ema.hidayanti@walisongo.ac.id
}

\begin{abstract}
This study aims to describe Islamic guidance services in improving the cognitive function of heart disease patients at Sunan Kudus Hospital. The data source of this study were clergy and heart disease patients at Sunan Kudus Hospital. Data collected by observation, interview and documentation. Data analysis using Miles and Huberman's theory, began the collection, presentation, and inference of data. The results of this study indicate that heart disease patients at Sunan Kudus Hospital have a negative cognitive function that is the mind focuses on pain and death. The practice of Islamic guidance in improving the cognitive function of heart disease patients uses the direct method of visiting clergy in each patient's room. The indirect method is by using Qur'anic healing, namely by listening to verses of the Qur'an to the patient through the speaker. This guidance practice provides positive benefits to the cognitive function of the patient. This positive benefit is seen in the attention, memory and ways of solving the patient's problem. Patient's attention is no longer too focused on pain and death. Meanwhile the patient's memory by remembering Allah Almighty the mind becomes more calm, and the patient is able to find solutions to the problems being faced.
\end{abstract}

Keywords: Islamic guidance, heart disease, cognitive function 


\begin{abstract}
Abstrak
Penelitian ini bertujuan mendiskripsikan layanan bimbingan Islam dalam memperbaiki fungsi kognitif pasien penyakit jantung di RSI Sunan Kudus. Sumber data penelitian ini adalah tenaga rohaniwan dan pasien penyakit jantung di RSI Sunan Kudus. Data dikumpulkan dengan observasi, wawancara, dan dokumentasi. Analisis data menggunakan teori Miles dan Huberman, mulai pengumpulan, penyajian, dan penyimpulan data. Hasil penelitian ini menunjukkan bahwa pasien penyakit jantung di RSI Sunan Kudus memiliki fungsi kognitif negatif yaitu pikiran fokus pada rasa sakit dan kematian. Praktik bimbingan Islam dalam memperbaiki fungsi kognitif pasien penyakit jantung mengunakan metode langsung yakni kunjungan petugas rohaniwan pada setiap ruangan pasien. Metode tidak langsung dengan menggunakan Qur'anic healing yakni dengan mendengarkan ayat al-Qur'an kepada pasien melalui speaker. Praktik bimbingan ini memberikan manfaat positif terhadap fungsi kognitif pasien. Manfaat positif ini terlihat pada atensi, memori dan cara pemecahan masalah pasien. Atensi pasien tidak lagi terlalu fokus pada rasa sakit dan kematian. Sementara itu memori pasien dengan mengingat Allah Swt maka pikirannya semakin tenang, dan pasien mampu menemukan solusi dari permasalahan yang sedang dihadapi.
\end{abstract}

Kata Kunci: Bimbingan Islam, penyakit jantung, fungsi kognitif

\title{
Pendahuluan
}

Kasus kematian yang diakibatkan oleh penyakit jantung masih menjadi persoalan di berbagai negara yang perlu dikaji lebih dalam lagi. Di negara Amerika, Asia dan Eropa 40\% warganya meninggal akibat penyakit tersebut dan $50 \%$ warganya memiliki kualitas hidup yang kurang produktif yang disebabkan oleh penyakit kerusakan arteri. ${ }^{1}$ Berdasarkan data dari WHO, pada tahun 2005 kasus kematian sebanyak 58 juta jiwa dan 19 juta jiwa diantaranya disebabkan oleh penyakit jantung. ${ }^{2}$ Hasil penelitian lainnya juga menunjukkan bawha $60 \%$ kasus kematian di dunia diakibatkan oleh penyakit jantung koroner atau PJK. Sementara itu pada tahun 2002, WHO mencatat sebanyak lebih dari 7 juta jiwa

\footnotetext{
${ }^{1}$ Roizen dan Mehmet, Sehat Tanpa Dokter (Yogyakarta: B First, t.t.), 39.

${ }^{2}$ Nurfi Afriansyah, Rahasia Jantung Sehat: Dengan Makanan Berkhasiat (Jakarta: Kompas Media Nusantara, 2008), xi.
} 
meninggal akibat penyakit jantung koroner. Kasus kematian tersebut diperkirakan meningkat sampai 11 juta kasus kematian pada tahun $2020 .^{3}$

Di Indonesia kasus kematian akibat penyakit jantung dan pembuluh darah, menjadi peringkat pertama diantara penyakit kronis lainnya pada tahun 2000. Berdasarkan Survei Kesehatan Rumah Tangga atau SKRT tahun 2001, adalah sebesar $26,3 \%$ orang meninggal akibat penyakit jantung. Kasus kematian tersebut terus meningkat dan semakin terlihat pada usia 35 tahun ke atas. ${ }^{4}$ Hasil penelitian ini menjadi salah satu beban psikologis, terutama pada fungsi kognitif pasien penyakit jantung saat ini. Fungsi kognitif yang terganggu menjadi beban psikologis sehingga berdampak pula pada kondisi fisik pasien. Pasien harus beradaptasi dengan penyakitnya, kemudian memiliki rasa takut, khawatir, stress, depresi dan rasa penerimaan diri dengan penyakit kronis. ${ }^{5}$

Permasalahan fungsi kognitif pasien penyakit jantung, perlu mendapatkan penanganan yang tepat, yakni tidak hanya mendapakan pengobatan secara fisik saja. Bahkan penanganan permasalahan fungsi kognitif pasien penyakit jantung dapat menjadi aspek utama untuk mendukung kesembuhan fisik pasien. Pasien penyakit jantung memiliki kerentanan kognitif. Oleh sebab itu, kerentanan kognitif tersebut harus diperbaiki karena fungsi kognitif adalah kunci untuk kehidupan. Dimana segala hal berawal dari pikiran, dan pikiranlah yang mampu untuk memahami hal tersebut termasuk memahami gangguan pasikologis. ${ }^{6}$

Permasalahan fungsi kognitif di atas, dapat perbaiki dengan menggunakan metode dakwah, dimana pada hakikatnya dakwah adalah untuk mengajak pada kebaikan. Metode dakwah ini dikemas dalam bimbingan Islam dengan memperhatikan kondisi fisik maupun pasikologis pasien. Pasien dengan penyakit kronis seperti jantung, lebih labil kondisi psikologisnya. Pasien yang labil kondisi psikologisnya ditandai dengan menyalahkan Allah karena penyakitnya, selalu memikirkan penyakit yang diderita, dan menyalahkan keluarganya. Adapun metode dakwah yang digunakan yakni mengajak dan membimbing pasien untuk bersabar, bertawakal dan terus berusaha untuk selalu mencari pengobatan. Selain itu, pasien diberikan motivasi menatal, dukungan sosial dan dido'akan. Metode ini bertujuan untuk megajak pasien meyakini bahwa segala penyakit pasti ada obatnya, baik secara medis maupun non medis. Obat secara medis yakni dengan usaha berobat ke dokter dan secara non medis

${ }^{3}$ Fitriani Umar. dkk, "Perilaku Merokok dan Lingkungan Pemukiman Pasien Rawat Jalan Penyakit Jantung Koroner di Makassar" Jurnal Media Gizi Mayarakat Indonesia, Vol. 1, No. 1, Agustus 2011 (t.t.): 21

${ }^{4}$ Delima dkk, "Prevalensi dan Faktor Determinan Penyakit Jantung di Indonesia," Bul. Peneliti. Kesehatan. Vol. 37, No. 3, 2009. (t.t.): 143

${ }^{5}$ Ema Hidayanti, Dasar-Dasar Bimbingan Rohani Pasien. (Semarang: Karaya Abadi Jaya, 2015), 61-66.

${ }^{6}$ Helly dkk, Dasar-dasar teknik, konseling (Yogyakarta: Pustaka Pelajar, 2010), 232. 
adalah dengan bersabar, ikhlas atas kehendak Allah Swt. Tujuan lain dari bimbingan Islam adalah memberi nasihat, membantu pasien untuk menemukan solusi permasalahan yang dihadapai. Dengan demikian maka pasien akan mendapatkan kesehatan yang paripurna secara fisik, psikis, sosial dan religius sehingga menciptakan loyalitas dalam komunitas beragama. ${ }^{7}$

Penelitian ini merupakan penelitian kualitatif. Sumber datanya adalah dokter spesialis penyakit jantung RSI Sunan Kudus, tenaga Rohaniwan dan pasien penyakit jantung RSI Sunan Kudus. Teknik pengumpulan data yang digunakan adalah wawancara dan observasi. Analisis data menggunakan teori Miles dan Huberman, mulai pengumpulan, penyajian, dan penyimpulan data.

\section{Hasil dan Pembahasan}

\section{Konsep Bimbingan Islam}

Secara etimologis kata bimbingan merupakan terjemahan dari guidance. Kata guidance berasal dari kata guide yang bermakna menuntun, menunjukkan, memberi arahan, mempimpin, memberikan nasihat serta mengatur. Kata bimbingan memiliki berbagai makna yang menunukkan proses, memberi bantuan, individu, pemahaman diri serta lingkungan sekitar. Berdasarkan makna ini maka didapatkan sebuah pengertian bahwa bimbingan merupakan proses untuk memberi bantuan kepada individu agar mampu memahami diri, lingkungan sekitar dan tujuan hidup. Makna bimbingan dalam Kamus Besar Bahasa Indonesia adalah petunjuka atau penjelasan untuk mengerjakan suatu hal, selain itu bermakna pula memberi jalan, menuntun orang kearah yang lebih baik dari sebelumnya. ${ }^{8}$

Bimbingan Islam merupakan sebuah proses untuk memberikan bantuan pada setiap individu yang bermasalah. Permasalahan tersebut seperti kelemahan iman akibat problematika kehidupan yang sedang dihadapi. Di dalam hal ini, bimbingan Islam adalah proses untuk memberikan bantuan spiritual kepada pasien maupun keluarga yang sedang mengalami permasalahan berupa sakit. Bimbingan Islam menjadi salah satu obat dari problematika lainnya yang menyertai pasien dan keluarga, sehingga pasien dan keluarga mampu menjalani kehidupan sesuai dengan syariat agama Islam. Selain itu dapat pula menjalani ujian (sakit) dengan penuh ikhlas, sabar dan tawakal kepada Allah Swt.'

Pemaparan di atas dapat dipahami bahwa konsep bimbingan Islam secara umum merupakan kegiatan membantu individu yang sedang mengalami

\footnotetext{
${ }^{7}$ Agus Riyadi, "Dakwah Terhadap Pasien: Telaah Terbadap Model Dakwah Melalui Sistem Layanan Bimbingan Rohani Islam di Rumah Sakit” Jurnal Bimbingan Konseling Islam, Vol. 5, No. 2, Desember 2014. (t.t.): 247.

${ }^{8} \mathrm{H}$ idayanti, Dasar-Dasar Bimbingan Rohani Pasien., 21-22.

${ }^{9}$ Hidayanti, 21-24
} 
permasalahan spiritual. Selain itu permasalahan seperti akidah dan akhlak juga menjadi sasaran dari bimbingan Islam. Dengan bimbingan Islam ini, diharapkan individu akan memahami makna hidup sesuai dengan syariat agama Islam. Sementara itu, makan bimbingan Islam secara eksplisit adalah aktivitas membantu pasien dan keluarganya dalam mengahadapi permasalahan berupa sakit kronis (jantung). Bimbingan Islam bagi pasien dan keluarganya menjadi alternatif lain sebagai media dalam mencari obat secara non medis. Dengan demikian, bimbingan Islam menjadi aspek penting untuk mendukung penyembuhan fisik pasien.

\section{Tujuan Bimbingan Islam}

Praktik bimbingan Islam di rumah sakit adalah bentuk pengobatan secara holistik yang bertujuan agar pasien mencapai kesehatan yang paripurna. Adapun tujuan lainnya adalah sebagai berikut:

1. Memberikan kesembuhan paripurna pasien.

2. Agar pasien mengikuti perawatan sampai sembuh.

3. Memahamkan pasien tentang makna sehat dan sakit dalam Islam.

4. Menunjukkan bahwa kondisi jiwa berpengaruh pada badan.

5. Supaya pasien tenang menghadapi sakitnya

6. Pasien mampu menyesuaikan diri dengan penyakitnya.

7. Menentramkan pikiran pasien yang gelisah karena sakitnya.

8. Bimbingan tentang ibadah selama sakit.

9. Bimbingan sakaratul maut agar pasien mencapai husnul khotimah.

10. Menenangkan keluarga atas kematian pasien.

11. Agar pasien mampu menemukan solusi permasalahan yang dihadapi.

12. Agar pasien selalu berikhtiar untuk mencari obat kepada ahlinya.

13. Agar pasien selalu beribadah selama sakit dan sesai kemampuan.

14. Mengintakan segala sesuatu yang medukung penyembuhan, seperti memperhatikan kebersihan bangsal.

15. Memberi dukungan spiritual dan moral pada pasien yang akan operasi. ${ }^{10}$

Tujuan bimbingan Islam di atas adalah adanya tujuan akhir atau final destination. Adapun tujuan akhir dari bimbingan Islam tidak lain adalah agar pasien dan keluarga selamat dan memiliki kebahagiaan hidup di dunia dan akhirat, sehingga mampu mengembangkan fitrahnya sebagai manusia. Di dalam mengembangkan fitrah manusia adalah dengan mengikuti aturan dalam alQur'an dan as-Sunnah. Mengikuti aturan dalam al-Qur'an bahwa pertama, Allah Swt. merupakan pencipta manusia beserta kekuatan dan kelemahannya, sehingga Allah Swt. tahu bagaimana mengelola kekuatan dan kelemahan tersebut. Kedua, Allah Swt. menciptakan manusia dengan segala potensi yang dimiliki, sehingga Allah Swt. tahu bagaimana cara mengembangkan potensi tesebut. Ketiga adalah tujuan diciptakan manusia adalah untuk menjadi khalifah dan beribadah keapada

${ }^{10}$ Hidayanti, 24-26. 
Allah Swt. Keempat bahwa kitab al-Qur'an adalah kitab suci dan memiliki kebenaran universal dan mutlak, sehingga semua manusia harus patuh terhadap aturannya yang berlaku sepanjang kehidupan. ${ }^{11}$

Sementara itu tujuan secara khusus dari bimbingan Islam agar pasien penyakit jantung dapat menyelaraskan pikiran dan perilaku dengan baik. Apabila pasien mampu menyeimbangkan antara pikiran dan perilakunya, antara kebutuhan fisik dan psikisnya maka disitulah hakikat untuk menjadi manusia yang sesuai dengan aturan agama Islam. Sebagai suri tauladan, Rasulullah adalah manusia yang dijadikan sebagai panutan. Rasulullah adalah sebagaimana manusia pada umumnya yang menyembah Allah Swt. Selain itu Rasulullah juga memenuhi segala kebutuhannya dengan apa yang telah ditetapkan oleh Allah Swt. tanpa berlebihan. Rasulullah juga selalu memperhatikan kesehatannya sehingga dapat beribadah dengan tenang kepada Allah SWT. ${ }^{12}$

\section{Fungsi Kognitif Pasien Penyakit Jantung}

Makna kognitif adalah kecenderungan individu untuk menyelaraskan antara aspek emosi dengan pikiran. Emosi dalam hal ini adalah kemarahan, dimana kebanyakan individu beremosi tetapi tanpa berpikir terlebih dahulu. Hal itu diakibatkan oleh berbagai perasaan yang dicetuskan oleh sudut pandang atau persepsi dari situasi yang spesifik. Demikian halnya dengan istilah kognitif merupakan bagian dari domain dan wilayah psikologi individu. Di mana ranah psikologi itu meliputi pertimbangan, pemahaman, proses pengolahan informasi, cara penyelesaian masalah serta aspek keyakinan. Selain itu pula ranah psikologi yang berpusat pada otak juga memiliki kaitan dengan konasi atau kehendak dan afeksi atau perasaan individu. ${ }^{13}$

Di dalam literatur yang lain disebutkan bahwa adanya komponen kognitif yakni berkaitan dengan aspek pengetahuan dan pemahaman individu. Mulai dari pengetahuan yang sedikit sampai pada pengetahuan secara menyeluruh dan mendalam. Oleh sebab itu perlu adanya disiplin keilmuan yang membahas tentang ranah kognitif dan salah satunya adalah disiplin ilmu psikologi kognitif. Psikologi kognitif merupakan ilmu yang mempelajari pola pikir individu. Psikologi kognitif juga merupakan studi tentang proses-proses yang mendasari dinamika mental individu. Ranah kognitif dalam hal ini adalah segala sesuatu yang mencakup aktivitas mental atau otak. Selain itu pula, kognitif juga diartikan sebagai kecerdasan pikiran serta cara mengamati suatu hal. ${ }^{14}$

${ }^{11}$ A nwar Sutoyo, Bimbingan dan Konseling Islam (Teori dan Praktik) (Yogyakarta: Pustaka Pelajar, 2014), 24-25

${ }_{12}^{12}$ Musfir bin Said Az-Zahrani, Konseling Terapi (Jakarta: Gema Insani Press, 2005), 409-10.

${ }^{13}$ Muhibbin Syah, Psikologi Belajar (Jakarta: Logos, 1999), 21-22

${ }^{14}$ Suranto AW, Komunikasi Interpersona (Yogyakarta: Graha Ilmu, 2011), 21-22 
Berdasarkan uraian tersebut, maka fungsi kognitif merupakan cara individu dalam berpikir. Berpikir dalam hal ini yakni dalam merespon stimulus dari luar dirinya yang ditangkap oleh panca indera dan kemudian menimbulkan reaksi. Fungsi kognitif adalah kemampuan individu dalam hal perhatian, ingatan, pertimbangan, mencari solusi masalah, dan kemampuan untuk merencanakan suatu hal, melakukan penilaian, kemampuan untuk mengawasi, serta kemampuan untuk melakukan evaluasi. ${ }^{15}$ Di dalam hal ini, fungsi kognitif pasien penyakit jantung dapat diartikan bahwa bagaimana aspek perhatian, memori dan penyelesaian dalam menghadapi permasalahan hidup, terutama dalam menghadapi penyakit yang sedang diderita. Seringkali pasien berpikir bahwa penyakit kronis seperti jantung adalah penyakit yang susah disembuhkan dan dekat dengan kematian, dan ini menjadi salah satu kesalahan berpikir sehingga berkaibat pada kondisi fisik pasien.

\section{Indikator Fungsi Kognitif Pasien}

\section{Atensi Pasien Penyakit Jantung di RSI Sunan Kudus}

Atensi atau biasa disebut dengan perhatian adalah proses mental yang diakibatkan adanya stimulus dari luar. Rangkaian stimulus itu menonjol pada kesadaran pada saat stimulus yang lainnya melemah. Atensi terjadi apabila individu mampu mengkonsentrasikan pikirannya menggunakan salah satu dari alat indera, serta mengacuhkan stimulus-stimulus yang lainnya. ${ }^{16}$ Atensi juga merupakan proses pemusatan pikiran secara jernih dari sejumlah stimulusstimulus yang ada. Pemusatan pikiran atau facalization kecerdasan merupakan inti dari atensi itu sendiri. Berbicara menganai atensi yang dilihat dari sudut pandang psikolog kognitif di era sekarang, adalah merupakan pemrosesan informasi dengan menyeleksi informasi tersebut dari sekeliling individu. Dengan demikian, otak secara penuh menerima berbagai informasi yang sangat banyak. Atensi bermakna pula pada pusatan mental pada berbagai peristiwa mental. ${ }^{17}$

Di dalam kaitannya dengan atensi pasien penyakit jantung, maka segala sesuatu informasi yang didapatkan oleh pasien mengenai bahaya penyakit jantung akan diproses oleh pasien itu dengan cara yang berbeda-beda. ${ }^{18}$ Idealnya, pasien yang memiliki tingkat spiritual baik atau akidah dan keyakinannya tinggi, akan lebih bagus dalam merespon setiap informasi yang didapatkan. Namun sebaliknya, pasien yang memiliki tingkat spiritual kurang baik (seperti tidak percaya bahwa segala sesuatu telah ditentukan), maka cenderung mersepon negatif dari segala

15 Imelda Herman, "Hubungan Lama Hemodialisis Dengan Fungsi Kognitif Paisen Ginjal Kronik Yang Menjalani Hemodialisis di RSUD Abdul Moeloek Bandar Lampung” Jurnal Medula, Vol. 7 No. 5, Desember 2017 (t.t.): 18.

${ }^{16}$ Jalaluddin Rahmat, Psikologi Komunikasi (Bandung: Remaja Rosdakarya, 1996), 52.

${ }^{17}$ Mahardika Andri, dkk, "Proses Atensi Pengetahuan Pada Siswa Attention Deficit Hyperactivity Disorder (ADHD) Dalam Memecabkan Masalah Matematika Materi Aritmetika Sosial' Jurnal Edu Sains, Vol. 5 No. 1, Januari 2016 (t.t.): 12.

${ }^{18}$ Wawancara dengan Dokter Spesialis Penyalit Jantung RSI Sunan Kudus 
informasi yang didapatkan mengenai penyakit jantung. Adapun respon negatif tersebut ditunjukkan dengan marah, menyalahkan keluarga dan acuh tak acuh terhadap penyakitnya. ${ }^{19}$

Uraian di atas menunjukkan bahwa atensi pasien penyakit jantung di RSI Sunan Kudus yang memfokuskan pada hal negatif terhadap penyakit jantung, semkain membuat kondisi fisik mereka melemah. ${ }^{20}$ Akan tetapi sebaliknya jika pasien mampu mengolah informasi mengenai penyakit jantung dengan baik dan benar, maka kondisi fisik pasien akan semakin membaik dan menajdi salah satu obat bagi pasien itu sendiri.

\section{Memori Pasien Penyakit Jantung di RSI Sunan Kudus}

Setiap manusia dilengkapi dengan berbagai kemampuan yang dapat digunakan sebaik mungkin dalam kehidupannya. Salah satau kemampuan tersebut adalah kemampuan untuk mengingat atau biasa dekatakan dengan memori. Ingatan berguna bagi setiap manusia guna menyimpan beragam informasi yang diperoleh dari stimulus-stimulus lingkungan. Dalam sebuah litertur disebutkan bahwa salah satu kelebihan manusia adalah memiliki daya ingat dibandingan dengan makhluk yang lainnya. Kelebihan menyimpan informasi tersebut dapat berjumlah sangat banyak dan mampu untuk dapat mengingatkanya kembali. ${ }^{21}$

Di dalam kaitannya dengan memori atau ingatan pasien penyakit jantung di RSI Sunan Kudus, menunjukkan dua hal yang berbeda. Sebagian pasien lebih mengingat akan datangnya kematian secara tiba-tiba dan ada pula yang sangat optimis untuk bisa sembuh. ${ }^{22}$ Apabila pasien selalu mengingta hal buruk seperti datangnya kematian seara tiba-tiba, maka akan semakin memperburuk kondisi bandannya. ${ }^{23}$ Oleh sebab itulah perlunya bimbingan Islam untuk mengingatkan kembali kepada pasien bahwa segala sesuatu permasalahan termasuk penyakit pasti ada jalan keluarnya. Adapun jalan keluarnya adalah dengan terus mencari pengobatan medis dan non medis seperti mendekatkan diri pada Allah Swt. sehingga pasien tidak selalu ingat pada rasa sakit yang dialami.

Ingatan yang kurang baik tesebut harus dikurangi dari pikiran pasien yang dalam keadaan tidak sehat. Ingatan-ingatan yang negatif tersebut perlu diganti dengan mengingat hal-hal positif seperti mengingat Allah Swt. dan Rasulullah. ${ }^{24}$ Adapun tujuan dari mengurangi ingatan yang kurang baik tersebut

\footnotetext{
${ }^{19}$ Wawancara dengan Dokter Spesialis Penyalit Jantung RSI Sunan Kudus

${ }^{20}$ Wawancara dengan Dokter Spesialis Penyalit Jantung RSI Sunan Kudus

${ }^{21}$ Muchsin Effendi dan Faizah, Faizah dan Muchsin Effendi. 2006. Psikologi Dakwah. Jakarta: Kencana. (Jakarta: Kencana, 2006), 154.

${ }^{22}$ Wawancara Pasien Penyalit Jantung RSI Sunan Kudus

${ }^{23}$ Wawancara dengan Dokter Spesialis Penyalit Jantung RSI Sunan Kudus

${ }^{24}$ Wawancara dengan Tenaga Rohaniwan Penyakit Jantung RSI Sunan Kudus
} 
tidak lain adalah untuk mendukung proses penyembuhan yang sedang dijalani di rumah sakit. Selain itu pula, mengingat hal positif adalah untuk memperbaiki diri dalam menjalani kehidupan.

\section{Pemecahan Masalah Pasien Penyakit Jantung di RSI Sunan Kudus}

Proses pemecahan masalah setiap individu adalah berbeda-beda. Pada umumnya individu dalam menyelesaikan permasalahan adalah sesuai kebiasaan yang dilakukannya. Sebagaimana dengan perilaku yang lainnya, bahwa pemecahan masalah dapat dipengaruhi oleh faktor situasi diri individu tersebut. Faktor-faktor tersebut dapat berupa adanya motivasi, memiliki keyakinan serta sikap yang tidak tepat, dipengaruhi oleh kebiasaan, dan dipengaruhi pula oleh emosi individu itu sendiri. ${ }^{25}$

Berdasarkan uraian tersebut maka cara penyelesaian masalah atau proses pemecahan masalah pasien penyakit jantung di RSI Sunan Kudus perlu tindakan yang tepat, supaya menghasilkan keputusan yang diharapkan. Hal itu dikarenakan permasalahan yang sering dihadapi pasien adalah antara permasalahan akan lamanya proses penyembuhan dan kematian. Adapun letak peran bimbingan Islam bagi pasien penyakit jantung untuk membantu pasien agar mampu menyelesaikan permasalahannya dengan baik dan benar sesuai dengan ketentuan dari Allah Swt. apabila pasien telah mampu menyelesaikan permasalahannya tersebut, maka diharapkan pasien akan mendapatkan kesembuhan yang paripurna yakni sehat secara bio-psiko-soiso dan religio.

\section{Penyakit Jantung}

1. Penyakit jantung koroner

Salah satu penyakit kronis adalah penyakit jantung koroner atau disebut dalam dunia medis adalah PJK. Penyakit ini menjadi penyakit pembunuh nomor satu di dunia. Adapun penyebab terjadinya penyakit jantung koroner adalah aliran darah pada pembuluh darah utama jantung yang tersembat. Hal itu dikarenakan adanya tumpukan lemak bahkan kolesterol di dinding pembuluh darah. Penumpukan lemak tersebut akan menimpulkan plak dan dalam dunia medis disebut dengan istilah ateroskelrosis, yaang mengahambat aliran darah. Kemudian akan timbul peradangan serta penyempitan pada pebuluh darah dan membuat darah sulit untuk mengalir ke jantung. Pada akhirnya jantung pun kekurangan darah yang kaya akan oksigen.

2. Penyakit katup jantung

Selain penyakit jantung koroner ada pula penyakit katup jantung. Penyakit ini terjadi pada katup jantung yang mengalami ketidaknormalan. Manusia memiliki empat katup jantung dimana katup-katup tersebut memiliki

\footnotetext{
${ }^{25}$ Wawancara dengan Tenaga Rohaniwan Penyalit Jantung RSI Sunan Kudus
} 
fungsi yakni pintu memisahkan antara ruang jantung. Adapun fungsi katup ini agar darah tidak berampur dan tidak ada darah yang kembali lagi. Katup jantung yang sakit, maka bentuknya tidak normal dan tidak sempurna. Ketidaknormalan tersebut ada yang kecil dan ada pula yang mengembang sehingga mengakibatkan katup tidak dapat menutup dan membuka dengan baik. Oleh sebab itu, darah menjadi bercampur dan dapat kembali lagi sehingga dinamakan penyakit katup jantung.

3. Penyakit jantung rematik

Penyakit jantung lainnya adalah penyakit jantung rematik. Penyakit ini merupakan suatu penyakit yang menyerang katup jantung. Penyakit jantung rematik yang disebabkan oleh infeski demam rematik dan menyerang tenggorokan. Dimana infeksi demam rematik ini berasal dari streptokokus dengan tipe A atau yang disebut dengan streptococcus pyogenes. Adapun ketika bakteri ini berada atau bersarang pada tenggorokan, ada beberapa bakteri yang turun dan kemudian menyerang jantung. Kemudian pada jantung itu sendiri, khususnya katup jantung akan mengalami pembengkakakan serta timbul jaringan parut di pintu katup dan hal itu disebut dengan valve. ${ }^{26}$

\section{Pelaksanaan Layanan Bimbingan Rohani Islam sebagai upaya Memperbaiki Fungsi Kognitif Pasien Penyakit Jantung di RSI Sunan Kudus Sebagai Bentuk Dakwah}

Manusia merupakan makhluk yang multidimensi. Artinya manusia dibentuk dengan beberapa dimensi seperti bio-psiko-sosio-dan religio. Berbagai dimensi tersebut harus terpenuhi segala kebutuhannya agar manusia dapat tumbuh menjadi makhluk yang paripurna. Makhluk yang paripurna ditandai dengan kesejahteraan pada aspek kesehatannya yang senantiasa menunjukkan kebaikan. Diri yang sehat secara komprehensif tersebut, sangat diharapkan oleh siapapun terutama oleh pasien yang sedang di rawat di rumah sakit. ${ }^{27}$

Pasien penyakit jantung yang dirawat, memiliki bermacam kebutuhan dan harus terpenuhi di rumah sakit. Guna memenuhi kebutuhan tersebut, pihak rumah sakit menyediakan sumber bantuan seperti dokter spesialis jantung sebagai layanan medis dan rohaniwan sebagai layanan non medis. ${ }^{28}$ Layanan non medis ini untuk mengatasi kegelisahan, kecemasan dan stress. ${ }^{29}$ Permasalahan psikologis ini dialami oleh pasien penyakit jantung di RSI Sunan Kudus. Adapun penyebab dari kegelisahan, stress dan khawatir adalah dari malfungsi kognitif pasien. Permasalahan fungsi kognitif itu membuat pasien semakin terpuruk dan

\footnotetext{
${ }^{26}$ https://drjantung.com/jenis-jenis-penyakit-jantung diakses pada 25 Januari 2018, pukul 9:56 WIB," t.t.

${ }^{27}$ Wawancara dengan Dokter Spesialis Penyalit Jantung RSI Sunan Kudus

${ }^{28}$ Wawancara dengan Direktur RSI Sunan Kudus

${ }^{29}$ Wawancara dengan Dokter Spesialis Penyalit Jantung RSI Sunan Kudus
} 
larut dalam penyakitnya. Dengan demikian, perlu adanya tindakan tepat sasaran guna mengatasi permasalahan fungsi kognitif tersebut.

Adapun usaha yang dilakukan adalah dengan mengajak pasien agar selalu berpikir positif dan mampu mengambil hikmah dari sakitnya. Usaha tersebut merupakan usaha dakwah untuk pasien agar senantiasa berada pada jalan yang benar, meskipun dalam kondisi sakit. Aktivitas dakwah yang dilakukan adalah dengan dakwah fardiyah, yakni memberikan pengertian kepada pasien, rasa senang, adanya kekuatan hubungan sosial yang baik dan kemampuan untuk memahami kondisi yang sebenarnya. ${ }^{30}$ Adapun dampak psikologis dari dakwah fardiyah adalah mampu menambah wawasan pasien tentang makna sakit dan cara penangangannya dengan tepat. Dengan demikian maka kesehatan psikologis pasien akan terpenuhi dan berdampak pada kesehatan fisiknya. ${ }^{31}$

Berdasarkan urian tersebut, maka kesehatan pada hakikatnya bukan hanya terletak pada kondisi badan saja, akan tetapi kondisi rohani pun menjadi salah satu aspek kategori kesehatan. Dimana kesehatan rohani berasal dari fungsi kognitif yang baik. Artinya fungsi kognitif pasien penyakit jantung yang senantiasa memperhatikan, mengingat dan mampu memecahkan permasalahannya sendiri dengan baik dan sesuai dengan yang didinginkan. Indikator perhatian, ingatan dan pemecahan masalah yang baik adalah dengan senantiasa berpedoman pada tuntunan al-Qur'an dan as-Sunnah. Dengan demikian maka kondisi fungsi kognitif yang baik, akan berdampak pada kondisi fisik pasien.

\section{Penutup}

Permasalahan fungsi kognitif pasien penyakit jantung di RSI Sunan Kudus menunjukkan kondisi yang kurang baik sebelum mendapatkan layanan bimbingan Islam. Adapun atensi pasien yang fokus pada masalah pekerjaan, rasa sakit serta permasalahan ekonomi keluarganya. Selain itu pula perhatian pasien yang fokus pada masalah penyakit berat dan datangnya kematian secara tiba-tiba. Adapun aspek memori pasien yang mengingat anaknya meninggal secara tibatiba, kemudian ada yang mengingat nasib anak-anak ketika pasien sakit, dan rasa sakit yang dialami ketika kambuh. Sementara itu aspek pemecahan masalah yang dilakukan pasien dengan mendekatkan diri pada Allah SWT. dengan beristigfar, melaksanakan shalat tahajud dan menekuni hobi pasien.

Praktik bimbingan Islam di RSI Sunan Kudus dalam memperbaiki fungsi kognitif pasien penyakit jantung dilakukan dua metode. Pertama adalah metode langsung yang dilakukan dengan rohaniwan melakukan kunjungan ke ruang pasien, kemudian memberikan nasihat, motivasi dan do'a. Sedangkan metode

\footnotetext{
${ }^{30}$ Wawancara dengan Tenaga Rohaniwan Penyalit Jantung RSI Sunan Kudus

${ }^{31}$ Wawancara dengan Tenaga Rohaniwan Penyalit Jantung RSI Sunan Kudus
} 
tidak langsung dilakukan dengan Qurnaic Healing kepada pasien. Qurnaic Healing adalah mendengarkan pasien ayat-ayat suci al-Qur'an dengan menggunakan speaker. Berdasarkan kedua metode tersebut berdampak positif pada fungsi kognitif pasien yang baik. Adapun fungsi kognitif yang baik ditandai dengan atensi yang tidak telalu fokus pada masalah penyakitnya, kemdudian ingatan yang selalu mengingat Allah Swt. dan cara pemecahan masalah yang didasarkan pada tututan al-Qur'an dan as-Sunnah. 


\section{Bibliografi}

Afriansyah, Nurfi. Rahasia Jantung Sehat: Dengan Makanan Berkhasiat. Jakarta: Kompas Media Nusantara, 2008.

Andri, dkk, Mahardika. "Proses Atensi Pengetahuan Pada Siswa Attention Deficit Hyperactivity Disorder (ADHD) Dalam Memecahkan Masalah Matematika Materi Aritmetika Sosial" Jurnal Edu Sains, Vol. 5 No. 1, Januari 2016 (t.t.).

Asmaya, Enung. "Aktivitas Dakwah Fardiyah Dalam Tinjauan Psikologi” Jurnal Dakwah dan Komunikasi. Vol. 1 No. 1 Januari-Juni 2007. (t.t.).

AW, Suranto. Komunikasi Interpersona. Yogyakarta: Graha Ilmu, 2011.

Az-Zahrani, Musfir bin Said. Konseling Terapi. Jakarta: Gema Insani Press, 2005.

dkk, Delima. "Prevalensi dan Faktor Determinan Penyakit Jantung di Indonesia," Bul. Peneliti. Kesehatan. Vol. 37, No. 3, 2009. (t.t.).

dkk, Helly. Dasar-dasar teknik konseling. Yogyakarta: Pustaka Pelajar, 2010.

Faizah, Muchsin Effendi dan. Faizah dan Muchsin Effendi. 2006. Psikologi Dakwah. Jakarta: Kencana. Jakarta: Kencana, 2006.

Herman, Imelda. "Hubungan Lama Hemodialisis Dengan Fungsi Kognitif Paisen Ginjal Kronik Yang Menjalani Hemodialisis di RSUD Abdul Moeloek Bandar Lampung” Jurnal Medula, Vol. 7 No. 5, Desember 2017 (t.t.).

Hidayanti, Ema. Dasar-Dasar Bimbingan Rohani Pasien. Semarang: Karaya Abadi Jaya, 2015.

"https://drjantung.com/jenis-jenis-penyakit-jantung diakses pada 25 Januari 2018, pukul 9:56 WIB," t.t.

Mehmet, Roizen dan. Sehat Tanpa Dokter. Yogyakarta: B First, t.t.

Rahmat, Jalaluddin. Psikologi Komunikasi. Bandung: Remaja Rosdakarya, 1996.

Riyadi, Agus. "Dakwah Terhadap Pasien: Telaah Terhadap Model Dakwah Melalui Sistem Layanan Bimbingan Rohani Islam di Rumah Sakit" Jurnal Bimbingan Konseling Islam, Vol. 5, No. 2, Desember 2014. (t.t.).

Sutoyo, Anwar. Bimbingan dan Konseling Islam (Teori dan Praktik). Yogyakarta: Pustaka Pelajar, 2014.

Syah, Muhibbin. Psikologi Belajar. Jakarta: Logos, 1999. 
106 | Islamic Counseling: Jurnal Bimbingan dan Konseling Islam, Vol. 4, No. 1, 2020

Umar. dkk, Fitriani. "Perilaku Merokok dan Lingkungan Pemukiman Pasien Rawat Jalan Penyakit Jantung Koroner di Makassar" Jurnal Media Gizi Mayarakat Indonesia, Vol. 1, No. 1, Agustus 2011 (t.t.). 